\title{
PENGAJARAN 3 BAHASA (INGGRIS-ARAB-JEPANG) DI MADRASAH INFORMAL KELURAHAN CIPADUNG
}

\author{
KECAMATAN CIBIRU \\ Puspa Mirani Kadir1, Isye Herawati ${ }^{2}$, Budi Rukhyana ${ }^{3}$ \\ ${ }^{1}$ Prodi Sastra Jepang, Universitas Padjadjaran \\ ${ }^{2}$ Prodi Sastra Jepang, Universitas Padjadjaran \\ ${ }^{3}$ Prodi Sastra Jepang, Universitas Padjadjaran \\ Email: ${ }^{1}$ puspa.mirani@unpad.ac.id, ${ }^{2}$ isye.herawati@unpad.ac.id, ${ }^{3}$ budi.rukhyana@unpad.ac.id
}

\begin{abstract}
ABSTRAK
Kuliah Kerja Nyata (KKN) merupakan proses pengetahuan dan teknologi pengayaan sumber belajar. Kegiatan KKN Mahasiswa Universitas Padjadjaran berlangsung dari tanggal 15 Desember 2020 sampai 15 Februari 2021. Lokasi KKN bertempat di Masjid Al-Huda Cipadung, Kecamatan Cibiru, Kota Bandung. Di masjid tersebut terdapat kegiatan pelatihan tiga bahasa, yaitu Bahasa Arab, Bahasa Inggris, dan Bahasa Jepang. Selain itu, terdapat sebuah perpustakaan yang dibangun untuk menumbuhkan minat baca terhadap anak-anak di lingkungan setempat. Para orang tua di lingkungan ini memiliki peran besar dalam membentuk lingkungan tempat tinggal yang nyaman dan ramah anak dengan adanya kegiatan di Majelis Ta'lim, Juma'at Berkah, dan lain sebagainya. Melalui hal tersebut tradisi gotong royong masyarakat Indonesia dapat dipertahankan dengan baik. Para orang tua juga membimbing anak-anak usia sekolah untuk rajin mengikuti pengajaran tiga bahasa yang dilaksanakan di Masjid Al-Huda untuk bekal bagi anak-anak di masa depan. Untuk menjawab bagaimana keberlangsungkan pengajaran dan sebagai bahan evaluasi, telah dikeluarkan kuesioner yang diisi oleh orangtua siswa. Angket ini berisi pertanyaan terhadap orangtua santri generasi alpha dalam pengajaran tiga bahasa untuk mengetahui sejauh mana komunikasi yang terjalin antara ibu dan anak terhadap pembelajaran 3 bahasa asing ini. Hasil dari survey KKN ini, terlihat komunikasi yang terjalin erat antara Ibu dan anak dalam mempelajari tiga bahasa asing di madrasah Al-Huda ini dan memberikan energi positif baik kepada santrinya sendiri maupun kepada pengajarnya.
\end{abstract}

Kata Kunci : generasi Alpha ,KKN, Pengajaran Tiga Bahasa

\section{PENDAHULUAN}

Pengelolaan MDT di Kelurahan Cipadung, khususnya di MDT Al-Huda, Asholihat, dan AlHikmah dalam hal kurikulum terdiri dari mata pelajaran agama utama yang menjadi kebutuhan umum masyarakat, yakni seperti mata pelajaran Al-Qur'an, Al Hadits, Sejarah Kebudayaan Islam, Fiqih, Tauhid, bahasa Arab dan Akhlak. Kurikulum mata pelajaran ini sudah disesuaikan isi kurikulum MDT Kementrian Agama, yang diarahkan pada upaya peningkatan keimanan dan ketakwaan anak didik kepada Alloh.SWT yang merupakan suatu kewajiban dasar orang Islam. Muatan kurikulum ini didesain sendiri dengan ditambah pelajaran lainnya sesuai misi dan tujuan MDT. Berdasarkan studi yang dilakukan oleh Kadir, Risagarniwa, dan Ma'mun (2020) bahwa pengajaran tiga bahasa asing ini akan efektif pengajarannya dalam atau setelah tiga tahun. Studi tersebut berusaha untuk menemukan metodologi pengajaran tiga bahasa yang tepat dan berusaha menciptakan suasana belajar yang dapat dinikmati oleh siswa. Selain itu, studi ini juga berusaha menciptakan fun-learning dengan tujuan untuk meningkatkan semangat siswa belajar bahasa asing.

Melalui program pekan kreatif mahasiswa (PKM), telah melakukan pengajaran tiga bahasa asing yaitu, Inggris, Arab, dan Jepang kepada anak-anak yang belajar di Madrasah Informal AlHuda Kelurahan Cipadung. Alasan objek sasaran dari kegiatan ini adalah karena Madrasah Al-Huda merupakan sekolah sasaran dari 
studi yang dilakukan oleh Kadir, Risagarniwa, dan Ma'ruf. Selain itu, madrasah ini juga menjadi lokasi pelaksanaan kegiatan kuliah kerja nyata (KKN) tahun 2018 dan tahun 2021. Bahasa yang diajarkan ketika kegiatan KKN juga bahasa yang sama dalam kegiatan PKM ini. Setelah kegiatan KKN dilaksanakan, disebarkan angket kepada orangtua wali murid siswa guna melihat evaluasi dari kegiatan pengajaran. Salah satu data yang terlihat di hasil angket yang telah disebar adalah data menunjukkan sebesar 77.4\% anak merasa cukup puas atas kegiatan pengajaran .

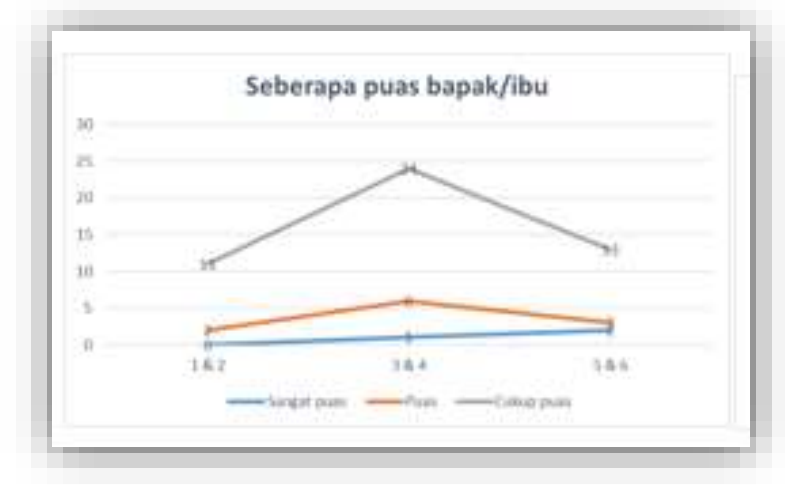

Grambar 1.Kepuasan Orangtua

Atas data itulah, program kreatif mahasiswa ini telah meningkatkan pengajaran tiga bahasa asing di madrasah ini dengan metode yang lebih baik lagi.

Diperlukan adanya dukungan untuk menjembatani siswa-siswi khususnya tingkat sekolah dasar untuk dapat mempelajari bahasa Inggris. Dengan adanya tempat belajar seperti madrasah informal akan membantu siswa-siswi belajar selain di lingkungan sekolah, maka dari itu lokasi yang menjadi pilihan tempat binaan kegiatan PKM ini adalah Madrasah Informal yang berlokasi di Komplek Cipadung Permai, Desa Cipadung, Kecamatan Cibiru, Kotamadya Bandung yaitu Madrasah Al-Huda. Madrasah Al-Huda merupakan taman pendidikan AlQur'an Informal yang mulanya didirikan pada tahun 1990 bertujuan untuk menyediakan sarana pengajaran baca tulis Al-Quran bagi anak usia sekolah. Dengan adanya progam ini, siswa Madrasah Al-Huda tidak hanya belajar baca tulis Al-Quran tetapi juga menambah pengetahuan Bahasa asing.
Madrasah ini pada awal tahun 1990 hanya mengajarkan baca tulis Al-Qur'an saja. Sejak 2009, pelajaran lain mulailah disampaikan seperti, aqidah akhlak, fiqih, quran hadist dan sejarah perkembangan islam. Seiring berjalannya waktu, adanya permohonan kepala madrasah Al-Huda setelah diadakan PKM tahun 2018 ingin menjalin mitra kerjasama dengan Fakultas Ilmu Budaya (FIB) Unpad. Mitra sangat berharap kegiatan pengajaran ini dapat ditingkatkan lagi untuk pengajaran 3 bahasa ini..

Kurangnya eksposur bahasa asing dalam lingkup Madrasah yang juga bukan merupakan bahasa pertama dan bukan mata pelajaran yang wajib dalam lingkup madrasah informal ini menjadi akar permasalahan timbulnya isu dalam pengajaran bahasa asing yang sangat berpegaruh pada antusiasme peserta didik. Maka dari itu perlu pengoptimalan program pengajaran 3 bahasa (Arab, Inggris, Jepang) ini.

Modul yang sudah dibuat pengajar 3 bahasa selama 3 (tiga) tahun berjalan ini perlu diperbaiki dalam latihan percakapan (conversation) untuk lebih menambah pengetahuan bahasa asing kepada anak-anak Madrasah tingkat pendidikan dasar dengan metode yang interaktif dan kreatif yang telah diaplikasikan pada peserta didik, yaitu dengan pengajaran audio visual kreatif berupa video animasi dan tes evaluasi berupa mini games.

Berdasarkan hasil angket yang telah dibagikan ke orang tua/wali kelas dua, tiga, dan empat mayoritas peserta didik belum pernah mengikuti pengajaran 3 Bahasa (Arab, Inggris, Jepang). Hanya bahasa Arab saja yang sudah dikenal mereka. Lain halnya siswa kelas 5-6 yang sudah diberikan dari 3 tahun yang lalu. Oleh karena itu orang tua/wali peserta didik memberikan dukungan penuh dan respon yang baik terhadap kegiatan ini, karena kegiatan ini merupakan hal yang baru, inovatif, dan efektif bagi mereka untuk mendukung kegiatan belajar anak-anaknya. Selain menumbuhkan minat dan mengembangkan pengetahuan siswa, mereka menginginkan kegiatan ini terus berlanjut kedepannya karena memberikan pengaruh yang signifikan bagi perkembangan pendidikan anakanak mereka terutama dalam perkembangan Bahasa pada anak. 
Permasalahan dalam pelaksanaan pendidikan di masa pandemi dan kurangya eksposur bahasa asing dalam lingkup Madrasah yang juga bukan merupakan bahasa pertama dan bukan mata pelajaran yang wajib dalam lingkup Madrasah menjadi akar permasalahan timbulnya isu dalam pengajaran Bahasa asing yang sangat berpegaruh pada antusiasme peserta didik. Terjadinya pandemi COVID-19 di Indonesia yang telah mengubah berbagai aspek kehidupan manusia, terutama dalam bidang pendidikan yang khususnya berdampak pada keberlangsungan kegiatan belajar mengajar di Madrasah Al-Huda.

Optimalisasi pelaksanaan KKN kali ini dengan melaksanakan survey melalui angket kepada orangtua siswa serta proses kegiatan mengajar yang interaktif selama 1 (satu ) bulan) memberikan dampak positif terhadap kerjasama antara Majelis ta'lim, dan madrasah serta kemajuan di bidang pengajaran di madrasah informal ini. Hal inipun tidak lepas dari tanggapan yang baik dari DKM Al-Huda yang selalu mendukung terhadap kegiatan KKN periode tahun 2020-2021.

Orang dewasa khususnya ibu-ibu yang memajukan lingkungannya melalui kegiatan Majelis Ta'lim dan mendidik anak-anaknya untuk belajar dengan baik telah tercipta dengan baik walaupun hasil yang dirasakan belum maksimal. Dari dua hal tersebut terciptalah kekompakan guna membangun daerah tempat tinggal yang lebih baik. Kami dapat menyimpulkan bahwa peranan pengajaran tiga bahasa asing khususnya di madrasah in-fomral ini sangat penting untuk peningkatan kualitas sumber daya manusia dan kualitas lingkungan tempat tinggal di Kecamatan Cibiru, Kota Bandung, khususnya daerah Cipadung, agar motivasi yang ditanamkan sejak kecil akan muncul kelak mereka dewasa. Mudah-mudahan Pembelajaran bahasa asing yang telah dipelajari ini, memberikan wawasan baru ketika mereka belajar di sekolah formal ke jenjang yang lebih tinggi.

\section{METODE PELAKSANAAN}

Pelaksanaan pengajaran tiga bahasa ini telah dilaksanakan dengan metode blended activity yaitu secara virtual dengan media komunikasi @Puspa Mirani Kadir.et.al daring seperti Google Meet dan Zoom yang dikombinasikan dengan kegiatan pengajaran setiap minggunya dilaksanakan secara tatap muka. Dikarenakan adanya padnemi COVID-19, kegiatan di lapangan (sinkronus) dilaksanakan sesuai protokol COVID-19 sangat memungkinkan dan dibutuhkan untuk kegiatan mengajar serta dilakukan oleh mahasiswa yang berada dekat dengan lokasi pengajaran dengan izin dari orang tua, dosen pembimbing, dan pihak madrasah.

Metode pengajaran yang digunakan pada kegiatan ini mengacu pada prinsip pembelajaran Aktif, Inspiratif, Inovatif, Kreatif, Efektif, dan Menyenangkan atau prinsip PAIKEM (Cook 1991). Metode ini kemudian diaplikasikan dengan pengajaran audio visual kreatif berupa video animasipengajaran kosakata dan cara penggunaan dengan bahasa sehari-hari yang ditampilkan melalui infocus dan tes evaluasi berupa mini games.

\section{HASIL DAN BAHASAN}

$\begin{array}{ccc}\begin{array}{c}\text { Pendekatan } \\ \text { pembelajaran }\end{array} & \begin{array}{c}\text { kontekstual } \\ \text { conversation }\end{array} & \begin{array}{c}\text { dalam } \\ \text { sebagai }\end{array}\end{array}$ keterampilan berbahasa asing termasuk penggunaaan berbagai media pembelajaran seperti video, audio, LCD, daftar kosa kata, bahan percakapan yang diambil dari sumber buku bahasa asing lainnya atau dibuat oleh pengajar sesuai dengan topik atau materi pelajaran, dan media dibuat oleh siswa. Komponen model bahan ajar ini juga mencakup penilaian teknik atau tes yang tidak hanya bentuk lisan tetapi juga tes tertulis. Pengajaran ini materi juga harus berisi teks dan latihan individu atau bahkan kelompok atau pasangan dan dilengkapi dengan bimbingan pengajar, sedangkan untuk siswa diberikan bahan ajar sebagai panduan saat belajar serta memperkuat keterampilan sesuai dengan pembelajaran bahasa asing tersebut.

Pendekatan kontekstual dalam pembelajaran conversation (kaiwa) juga sangat baik untuk memfasilitasi pencapaian tujuan pembelajaran, yaitu tujuan keterampilan berbahasa Jepang untuk meningkatkan kemampuan berbicara siswa dan memberikan banyak peluang untuk latihan berbicara dengan teman sambil membuat siswa terlibat 73 |K A i b o n A b h in a y 
aktif dalam proses pembelajarannya. Karena itu, siswa disarankan agar dalam belajar kaiwa selalu mengeluarkan ucapannya dengan jelas baik itu kosa kata ataupun kalimat sederhana.

Pengajar bahasa Inggris perlu menekankan motivasi belajar kepada siswa madrasah diniyah-awaliyah ini dengan menyelaraskan niat yang didukung oleh kemauan yang besar bahwa apa yang dipelajari adalah tuntutan dalam memperkaya diri dengan pemahaman yang baik terhadap bahasa Inggris umumnya. Pada pelajaran bahasa Inggris sedikit disajikan dialog umum sehari-hari sebagai bahan latihan dalam berpraktik dan menjawab pertanyaanpertanyaan baik secara perorangan maupun dengan partner belajar guna membantu meningkatkan percakapan sehari-hari dengan berbahasa Inggris.

Susunan kata dalam bahasa Inggris yang dipelajari pada segi tata bahasa perlu diajarkan lebih awal dengan diikuti latihan dan berlatih secara perorangan maupun bersama teman sekelas. Perlu ditekankan apapun bahasa yang dipelajari harus dihindari rasa bosan dalam belajar yang diakibatkan terlalu memforsir tenaga atau memaksakan diri.

Bahan ajar yang digunakan untuk pembelajaran ketiga bahasa Asing ini seperti yang dituturkan dalam (tabel.1) berikut.

Tabel.1 Buku Acuan di Madrasah In-formal

\begin{tabular}{|c|c|c|c|c|}
\hline $\begin{array}{l}\mathbf{N} \\
\mathbf{o}\end{array}$ & $\begin{array}{c}\text { Pokok } \\
\text { Bahasan }\end{array}$ & $\begin{array}{c}\text { Bahasa } \\
\text { Arab }\end{array}$ & Bahasa Inggris & Bahasa Jepang \\
\hline 1 & $\begin{array}{l}\text { Buku } \\
\text { acuan }\end{array}$ & $\begin{array}{l}\text { 'Al } \\
\text { Muqoddim } \\
\text { ah juz } \\
\text { Awal' }\end{array}$ & $\begin{array}{l}\text { A Stepping Stone } \\
\text { Toward } \\
\text { Mastering } \\
\text { English Grammar } \\
\text { (Qalam Media } \\
\text { Pustaka) }\end{array}$ & $\begin{array}{l}\text { Marugoto } \\
\text { Katsudou' } \\
\text { The Japan } \\
\text { Foundation- } \\
\text { Japan)Versi: } \\
\text { Bhs. Ind }\end{array}$ \\
\hline 2 & $\begin{array}{l}\text { Suplemen } \\
t\end{array}$ & $\begin{array}{l}\text { 'Mudah } \\
\text { Belajar } \\
\text { Bahasa } \\
\text { Arab' } \\
\text { (Grasindo) }\end{array}$ & $\begin{array}{l}\text { 'The Easiest } \\
\text { English } \\
\text { Conversation' } \\
\text { (Pustaka Grafika) }\end{array}$ & $\begin{array}{l}\text { 'Hiragana- } \\
\text { Katakana' } \\
\text { (The Japan } \\
\text { Foundation, } \\
\text { Tokyo-Japan) }\end{array}$ \\
\hline 3 & $\begin{array}{l}\text { audio } \\
\text { visual }\end{array}$ & $\begin{array}{l}\text { 'You } \\
\text { Tube:Ahka } \\
\text { mul } \\
\text { Qur'an- } \\
\text { An-Najwa' }\end{array}$ & $\begin{array}{l}\text { 'You Tube: 'Good } \\
\text { Collaboration', } \\
\text { dan } \\
\text { 'BTS Speech at } \\
\text { United Nations- } \\
\text { Unicef' }\end{array}$ & $\begin{array}{l}\text { 'Getsuyou Kara } \\
\text { Yoru } \\
\text { Fukashi'(Nippo } \\
\text { n Terebi) }\end{array}$ \\
\hline 4. & $\begin{array}{l}\text { Alat } \\
\text { bantu }\end{array}$ & Hand-out & Hand-out & Hand-out \\
\hline 5 & $\begin{array}{l}\text { UTS- } \\
\text { UAS }\end{array}$ & $\begin{array}{l}\text { Print-out } \\
\text { soal (essay } \\
\& \text { pilihan } \\
\text { berganda }\end{array}$ & $\begin{array}{l}\text { Print-out soal } \\
\text { essay dan pilihan } \\
\text { berganda }\end{array}$ & $\begin{array}{l}\text { Print-out soal } \\
\text { essay dan } \\
\text { pilihan } \\
\text { berganda }\end{array}$ \\
\hline
\end{tabular}

Video yang ditayangkan selain menambah kemampuan berbahasa juga sedikitnya memberikan pesan moral di dalam berkehidupan bersama-sama teman. Pemahaman siswa dapat didengar dari tuturan mereka setelah melihat tayangan video ini. Tuturan siswa mendekati pada jawaban yang tepat, sehingga pengajar akan terus mencoba pada pengajaran berikutnya melalui kolaborasi tayangan video-video lainnya.

Pengoptimalisasian dalam pengajaran 3 bahasa asing dengan estimasi waktu yang minimalis dapat dijalani pengajar dengan baik meskipun banyak faktor yang telah mempengaruhi terhadap kelancarannya. Tiga acuan buku yang digunakan di kelas sudah bisa diterima oleh para siswa, demikian juga penggunaan buku tambahan yang dapat dibaca di rumah karena buku ini sudah diberikan secara cuma-cuma pada saat pertama siswa masuk kelas. Tujuan penggunaan bahan ajar yang menggunakan audio visual akan diperjelas seperti di bawah ini.

Untuk pembelajaran bahasa Arab menggunakan video You Tube:'Ahkamul Qur'an- An-Najwa' yang berisi tentang pemahaman tentang pentingnya menghargai teman dengan tidak berbisik di hadapan teman yang lain agar tidak menimbulkan Suudzon yang akan menimbulkan perpecahan. Sedangkan untuk bahasa Inggris menggunakan video - You Tube: 'Good Collaboration', yang berisikan tentang pentingnya saling kerjasama dalam melaksanakan tugas dan saling menghormati satu dengan yang lainnya. Selanjutnya untuk bahasa Jepang menggunakan video youtube : 'Getsuyou Kara Yoru Fukashi' bertujuan untuk Pemahaman siswa dalam mendengar isi percakapan dan nyanyian dengan berlatih kembali melafalkannya nyanyian tersebut. Video yang ditayangkan selain menambah kemampuan berbahasa juga sedikitnya memberikan pesan moral di dalam berkehidupan bersama-sama teman. Pemahaman siswa dapat didengar dari tuturan mereka setelah melihat tayangan video ini. Tuturan siswa mendekati pada jawaban yang tepat, sehingga pengajar akan terus mencoba pada pengajaran berikutnya melalui kolaborasi tayangan video-video lainnya.

Pelaksanaan Ujian Tengah Semester dan Ujian Akhir Semester dapat diikuti oleh siswa 
dengan baik, meskipun ada siswa yang ujiannya menyusul dikarenakan sakit ataupun alasan lainnya.

Dalam pelaksanaan kegiatan ini, telah muncul beberapa keberhasilan yang telah dicapai. Kegiatan ini dapat meningkatkan minat serta konsentrasi anak-anak madrasah ketika mengikuti kegiatan pembelajaran. Mereka yang pada pertemuan pertama masih perlu dorongan untuk menyampaikan gagasannya pada pertemuan terakhir sudah dapat memberanikan dirinya untuk tampil dan menyampaikan gagasannya di depan temantemannya. Mereka juga lebih memahami apa yang disampaikan oleh para pengajar. Hal ini dapat terjadi dengan pengimplementasian multimedia sebagai sebuah media pembelajaran. Media ini dapat meningkatkan keikutsertaan anak-anak di madrasah ini. Rancangan tindak lanjut hasil kegiatan: Kegiatan tindak lanjut berupa rekomendasi hasil evaluasi kegiatan PPM ini yang dapat digunakan untuk mengembangkan metode pengajaran 3 bahasa di Madrasah Al-Huda.

Tindak Lanjut Kegiatan Perubahan yang terlihat sesudah melaksanakan kegiatan (perbandingan saat pretest-posttest, intensitas interaksi tiap pertemuan, dll) salah satunya adalah sikap para siswa dalam mengikuti pembelajaran 3 bahasa. Ketika pertemuan pertama, para siswa masih terkesan kurang tertarik serta banyak yang kurang memperhatikan apa yang dijelaskan oleh pengajar. Hal ini disebabkan oleh kurangnya pemahaman yang dimiliki oleh pengajar serta penggunaan media pembelajaran yang kurang menarik. Namun, setelah pertemuan ketiga, para siswa sudah memiliki minat serta berani dan mampu dalam mencetuskan ide-ide yang dimiliki oleh mereka. Hal ini dapat dicapai karena adanya penggunaan media penyampaian materi yang lebih menyenangkan dan menarik bagi para siswa. Selain itu, adanya permainan di dalam metode penyampaian materi juga ikut andil dalam meningkatkan minat para siswa. Oleh karena itu, tindak lanjut yang perlu dilakukan oleh para pengajar di Madrasah Informal Al Huda adalah dengan terus menerapkan metode serta media pembelajaran interaktif. Hal ini diperlukan dengan tujuan untuk meningkatkan keikutsertaan anak-anak ketika mengikuti kegiatan pembelajaran yang diberikan. Media pembelajaran interaktif juga dapat mendorong anak untuk lebih memperhatikan materi yang diberikan oleh pengajar ketika kegiatan pembelajaran sedang berlangsung. Para pengajar dapat meningkatkan penggunaan media pembelajaran seperti video edukatif serta powerpoint dengan menggunakan desain yang diminati oleh anak-anak. Hal ini dapat dilihat pada Gambar 2. Tentang suasana pengajaran 3 bahasa di Madrasah Al-Huda.

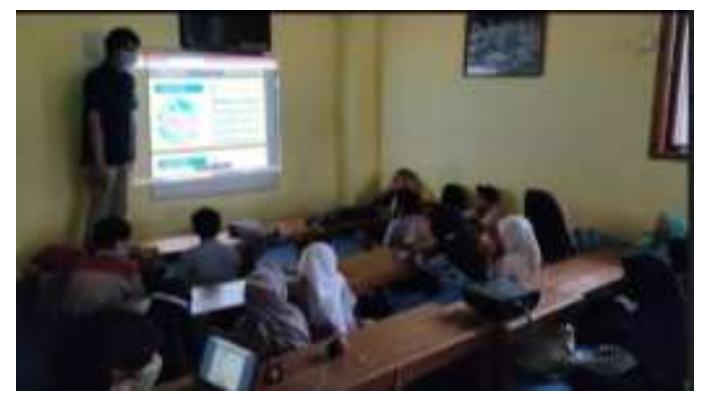

Gambar 2. Suasana Proses Belajar-Mengajar di Madrasah Al-Huda

Selain meningkatkan penggunaan multimedia pembelajaran, para pengajar juga dapat menggunakan berbagai jenis permainan edukatif. Penggunaan permainan dalam kegiatan akan membuat anak-anak menjadi lebih konsentrasi dan tidak merasa bosan ketika mengikuti kegiatan pembelajaran. Kegiatan ini terjalin hubungan yang akrab antar siswa dan guru, seperti terlihat dalam gambar 3 di bawah ini.

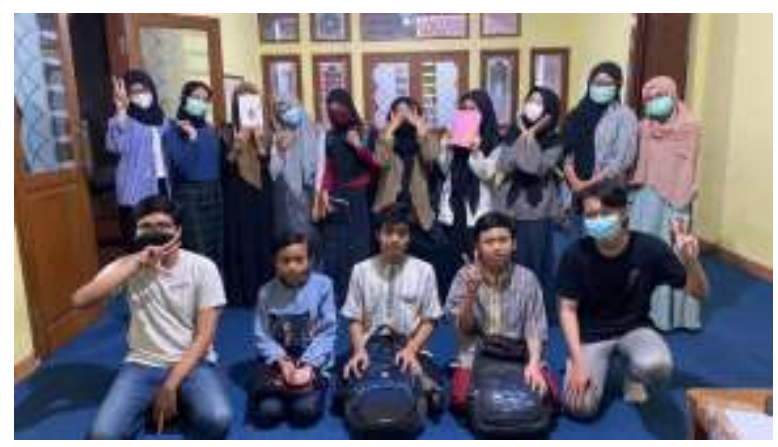

Gambar 3. Siswa kelas 5-6 DTA Bersama Guru Madrasah Al-Huda.

Penerapan metode pengajaran yang mengacu pada prinsip pembelajaran Aktif, Inspiratif, Inovatif, Kreatif, Efektif, dan Menyenangkan atau prinsip PAIKEM (Cook 
1991) ini yang diaplikasikan dengan pengajaran menggunakan peralatan audio visual yang kami miliki memberikan kontribusi yang baik dalam pengembangan proses kegiatan belajar-mengajar selanjutnya khsususnya di madrasah Al-huda ini.

\section{KESIMPULAN DAN SARAN Kesimpulan}

Dengan melalui kegiatan PKM Pengajaran 3 Bahasa (Inggris, Jepang, Arab) yang dilakukan di Madrasah Informal Al-Huda kecamatan Cipadung, Jawa Barat, dapat disimpulkan bahwa para siswa kelas 5-6 telah ditingkatkan minat serta konsentrasinya ketika mengikuti kegiatan pembelajaran. Kegiatan ini juga menggunakan metode serta media pembelajaran interaktif. Hal ini dapat meningkatkan keikutsertaan siswa ketika mengikuti kegiatan pembelajaran yang diberikan. Media pembelajaran interaktif serta permainan edukatif juga dapat mendorong anak untuk lebih memperhatikan materi yang diberikan oleh pengajar ketika kegiatan pembelajaran sedang berlangsung. Untuk selanjutnya, pengajaran di Madrasah Informal Al-Huda dapat terus menerapkan metode serta media pembelajaran interaktif, serta menggunakan powerpoint dengan menggunakan desain yang diminati oleh anakanak. Penggunaan permainan dalam kegiatan akan membuat anak-anak menjadi lebih konsentrasi dan tidak merasa bosan ketika mengikuti kegiatan pembelajaran. Metodemetode ini diharapkan dapat diimplementasikan pada kegiatan belajarmengajar untuk memaksimalkan penyerapan materi oleh siswa, serta kegiatan pengajaran dan pembelajaran itu sendiri.

\section{SARAN}

Dalam memunculkan minat siswa terhadap bahasa asing, materi yang disampaikan dapat dikaitkan dengan hal sehari-hari atau masa depan para siswa, sehingga siswa merasa materi yang disampaikan akan berguna dan menjadi antusias dalam pembelajaran. 1. Dapat di terapkan permainan edukatif pada awal pembelajaran untuk merangsang minat belajar dan konsentrasi siswa 2. Kegiatan student centered learning dapat juga meningkatkan interaksi antar pengajar maupun siswa serta memunculkan rasa ingin @Puspa Mirani Kadir.et.al tahu terhadap materi yang diajarkan 3. Media pembelajaran seperti video dan presentasi menarik yang disertai warna dan kartun juga dapat menjadikan kegiatan belajar lebih menarik.

\section{DAFTAR REFERENSI}

Al-khresheh, M. (2010). Interlingual interference in the English language word order structure of Jordanian EFL learners. European Journal of Social Sciences, 16(1), 106113.

Al-khresheh, M., Khaerurrozikin, A.,\&Zaid, A. (2020). The efficiency of using pictures in teaching speaking skills of non-native Arabic beginner students. Universal Journal of Educational Research, 8 (3), 872-878. https:// doi.org/10.13189/ujer.2020.080318

Cook, V. (1991). Second language learning and language teaching. London: Edward Arnold.

Fikri, S. (2011). A Stepping Stone Toward Mastering English Grammar. Qalam Media Pustaka, Jakarta.

Heath, J. (2005). The Arabic language and national identity: A study in ideology. Journal of Linguistic Anthropology, 15(2), 281 283.

https://doi.org/10.1525/jlin.2005.15.2.281

Hiromi, K. (2013). Marugoto: Japanese Language and Culture. The Japan Foundation, Tokyo.

Husen, H. (2010). The Easiest English Conversation. CV PustakaGrafika,Bandung. Kadir, P. M., Risagarniwa, Y. Y., \& Ma'mun, T. N. (2020)Arabic English Japanese Learning Program In Madrasah Diniyah Takmiliyah (Mdt): A Study On The Role Of Mdt In Bandung City: Humanities \& Social Sciences Reviews eISSN: 2395-6518, Vol 8, No 3, 2020, pp 824-835

https:// doi.org/10.18510/hssr.2020.8387

Murtadha, A. (2018). Introduction to simple Arabic. Al-Shafa: Bandung.

PeraturanMenteri Agama Republik Indonesia (2018). About graduates competency standards and content standards.

The Japan Foundation (1981). Nihongo KanaNyumon VersiBahasa Indonesia. Bonjinsha, Tokyo. 